\title{
PREFERENSI KONSUMEN TERHADAP KONSUMSI EDAMAME DI KABUPATEN JEMBER
}

Oleh :

BAMBANG POERWANTO *)

\begin{abstract}
ABSTRAK
Penelitian bertujuan : (a) Untuk mengetahui faktor yang membentuk preferensi konsumen terhadap edamame curah (segar) dan kemasan (beku). (b) Untuk mengetahui faktor yang mempengaruhi tingkat konsumsi edamame curah (segar) dan kemasan (beku); (c) Untuk mengetahui strategi pengembangan pasar lokal produk edamame. Teknis Analisis data meliputi (a) Untuk mengetahui faktor - faktor yang membentuk preferensi konsumen terhadap edamame edamame curah (segar) dan kemasan (beku) digunakan analisis faktor ; (b) Untuk mengetahui faktor yang mempengaruhi tingkat konsumsi edamame edamame curah (segar) dan kemasan (beku) digunakan uji regresi linier berganda; (c) Untuk mengetahui strategi pengembangan pasar lokal produk edamame dipergunakan analisis medan kekuatan atau Force Field Analysis. Hasil penelitian menunjukkan edamame dalam kemasan (beku) preferensi konsumen dalam pembelian di pengaruhi variable produk dan promosi, sedangkan harga edamame dan distribusi tidak memiliki pengaruh nyata. Edamame curah (segar) dalam pembelian di pengaruhi oleh promosi sedangkan harga edamame, produk dan distribusi tidak memiliki pengaruh secara nyata. Faktor-faktor yang membentuk preferensi konsumen edamame dalam kemasan (beku) yaitu kualitas edamame meliputi variabel rasa, aroma, warna. Faktor bauran pemasaran meliputi harga, distribusi/pengecer. Faktor kehandalan meliputi kebersihan, daya tahan produk, cepat saji. Faktor desain kemasan meliputi kapasitas isi dan merek. Faktor yang membentuk preferensi konsumen edamame curah segar yaitu faktor eksternal meliputi variabel pengecer, ukuran, jumlah polong, kecacatan dapat di beri identitas yang mewakili seluruh variabel dengan nama faktor eksternal. Faktor internal meliputi variabel : daya tahan produk, rasa, warna dan aroma. Hasil analisis force field analysis menyatakan factor pendorong utama dalam pengembangan edamame di Kabupaten Jember adalah kualitas ekspor edamame dan kedua adalah produk edamame yang tergolong baru dan belum banyak diketahui masyarakat. Sedangkan factor penghambat utama adalah promosi edamame yang memang belum dilaksanakan secara optimal dan kedua ketersediaan outlet produk edamame yang hanya terkonsentrasi di Jember.
\end{abstract}

Kata Kunci : Prefensi, Konsumsi, Edamame, Jember 



\section{PENDAHULUAN}

Pada tahun 2010, PT Mitratani Duatujuh berencana mengembangkan komoditi edamame di pasar lokal karena sebelumnya pihak perusahaan hanya berorientasi pasar ekspor. Peluang untuk mengembangkan edamame di Kabupaten Jember sekitar $35 \%$ dari total produksi edamame oleh Mitratani Dua Tujuh, sedangkan 65\% di ekspor. Dari penjelasan tersebut, maka dalam bahasan ini penulis memunculkan judul analisis preferensi konsumen terhadap konsumsi produk edamame di Kabupaten Jember karena komoditas ini dimungkinkan akan dapat memberikan alternatif bagi masyarakat akan pemenuhan kebutuhan edamame yang sampai saat ini masih diekspor ke negara lain.

Pada tahun 2011 sampai sekarang, PT Mitratani berencana mengembangkan pasar lokal Program pengembangan pasar ini tentunya harus didukung dengan informasi - informasi mengenai kebutuhan dan keinginan masyarakat sebagai pasar sasaran. Edamame yang telah dijual dipasar lokal terutama di Kabupaten Jember tidak hanya edamame beku segar seperti yang diekspor ke Jepang akan tetapi lebih banyak produk olahannya. Hal ini dilakukan untuk menarik minat beli masyarakat Jember.

Penelitian ini yang dilakukan di Kabupaten Jember bertujuan (1) Untuk mengetahui faktor faktor yang membentuk preferensi konsumen terhadap edamame curah (segar) dan kemasan (beku) di Kabupaten Jember ; (2) Untuk mengetahui faktor yang mempengaruhi tingkat konsumsi edamame curah (segar) dan kemasan (beku) di Kabupaten Jember, dan (3) Untuk mengetahui strategi pengembangan pasar lokal produk edamame di Kabupaten Jember.

Penentuan lokasi penelitian di Kabupaten Jember dengan pertimbangan bahwa Jember merupakan daerah tempat budidaya, pengolahan dan pemasaran edamame yang dilakukan oleh PT Mitratani 27 dan merupakan penghasil edamame terbesar di Indonesia. Metode penelitian ini adalah metode deskriptif analisis, yaitu metode yang memusatkan diri pada pemecahan masalah masalah yang ada. Data yang telah dikumpulkan, mula - mula disusun, dijelaskan kemudian dianalisis.. Data yang digunakan penelitian ini meliputi data primer. Teknik penentuan sampel dengan menggunakan teknik Accidental Sampling yaitu pengambilan sampel dengan jalan mengambil individu siapa saja yang dapat dijangkau atau ditemui.

digunakan analisis faktor ; (b) Untuk mengetahui faktor yang mempengaruhi tingkat konsumsi edamame curah (segar) dan kemasan (beku) di Kabupaten Jember digunakan uji regresi linier berganda; (c) Untuk mengetahui strategi pengembangan pasar produk edamame lokal di Kabupaten Jember dipergunakan analisis medan kekuatan atau Force Field Analysis.

\section{METODE PENELITIAN}

Dalam penelitian ini lokasi penelitian ditentukan secara sengaja (purposive) di Kabupaten Jember dengan pertimbangan (1) Kabupaten Jember merupakan daerah tempat budidaya, pengolahan dan pemasaran edamame yang dilakukan oleh PT Mitratani 27 : (2) merupakan penghasil edamame terbesar di Indonesia; dan (3). PT. Mitratani 27 mengolah edamame dan memasarkan produknya di Kabupaten Jember untuk edamame first grade (sebagian kecil) dan second grade (sebagian besar) melalui outlet atau retailer yang ada di Kabupaten Jember.

Adapun analisis yang akan digunakan adalah sebagai berikut:

a. Faktor - faktor yang membentuk preferensi konsumen dalam pengambilan keputusan untuk membeli edamame curah (segar) dan Kemasan (beku) di Kabupaten Jember. Model matematis dasar analisis faktor yang digunakan untuk setiap variabel independen $\mathrm{X}_{\mathrm{i}}$ (Wibisono, 2003)

$$
\begin{aligned}
X_{1} & =\sum_{i=I}^{m} A_{i j} F_{j}+b_{i} U_{i} \\
\mathrm{X}_{\mathrm{i}} & =\text { variabel independen ke }-\mathrm{i} \\
\mathrm{A}_{\mathrm{ij}} & =\text { koefisien faktor kesamaan } \\
\mathrm{U}_{\mathrm{i}} & =\text { faktor unik ke- } \mathrm{i} \\
\mathrm{b}_{\mathrm{i}} & =\text { koefisien faktor unik }
\end{aligned}
$$

b. Faktor - Faktor yang Mempengaruhi Konsumsi Edamame curah (segar) dan Kemasan (beku) di Kabupaten Jember. Untuk mengestimasi fungsi faktor - faktor yang mempengaruhi tingkat konsumsi edamame menggunakan OLS dengan model multiple regression dapat ditulis :

$$
\begin{aligned}
& \text { Qt }=\beta_{0}+\beta_{1} \text { HKE }+\beta_{2} \text { Prod }+\beta_{3} \text { Prom }+\beta_{4} \text { Dist }+\mathrm{e} \\
& \text { Keterangan : } \\
& \text { Qt } \quad=\text { tingkat konsumsi edamame }(\mathrm{kg}) \\
& \mathrm{HKE} \quad=\text { harga edamame } \\
& \text { Prod } \quad=\text { Produk } \\
& \text { Prom } \quad=\text { Promosi } \\
& \text { Dist } \quad=\text { Distribusi } \\
& \beta_{1} \beta_{2} \beta_{3} \beta_{4}=\text { Koefisien variabel } \\
& \mathrm{e} \quad=\text { faktor error }
\end{aligned}
$$

c. Strategi pengembangan pasar lokal edamame di Kabupaten Jember. Strategi pengembangan 
pasar lokal edamame di Kabupaten Jember menggunakan analisis medan kekuatan atau analisis FFA (Force Field Analysis )..

\section{HASIL DAN PEMBAHASAN}

\section{a. Faktor Yang Membentuk Preferensi Konsumen Dalam Pembelian Edamame dalam kemasan (beku).}

Terdapat 10 variabel yang dianalisis dapat membentuk preferensi konsumsi Edamame dalam kemasan (beku) yaitu harga, kebersihan, daya tahan produk, distribusi/pengecer, rasa, warna, aroma, merek, kapasitas isi, cepat saji. Pengujian dilakukan karena 10 variabel tersebut memiliki kecenderungan untuk mengelompok dan membentuk suatu faktor yang ditunjukkan dengan adanya korelasi kuat dengan variabel lain. Sebaliknya, jika antar variabel memiliki korelasi yang lemah maka variabel tersebut tidak akan mengelompok dalam faktor tertentu. Pada Tabel 1 dapat dilihat hasil pengujian standart deviasi dari 10 faktor.

Tabel 1. Hasil Pengujian Standar Deviasi

\begin{tabular}{lccccc}
\hline \multicolumn{1}{c}{ variabel } & $\mathrm{N}$ & Min & Maks & Mean & Std. Dev \\
\hline Harga & 50 & 2 & 5 & 3.76 & 0.84 \\
Kebersihan & 50 & 2 & 5 & 4.24 & 0.82 \\
Daya tahan produk & 50 & 2 & 5 & 4.14 & 0.80 \\
Keberadaan distribusi & 50 & 2 & 5 & 3.4 & 1.03 \\
Rasa & 50 & 2 & 5 & 4.0 & 0.69 \\
Warna & 50 & 3 & 5 & 4.26 & 0.63 \\
Aroma & 50 & 3 & 5 & 4.24 & 0.62 \\
Merek & 50 & 1 & 5 & 3.02 & 1.13 \\
kapasitas isi & 50 & 2 & 5 & 3.66 & 0.87 \\
cepat saji & 50 & 2 & 5 & 3.78 & 0.91 \\
Valid N (listwise) & 50 & & & & \\
\hline
\end{tabular}

Sumber: Data primer diolah

Pada Tabel 1 dapat dilihat bahwa tidak ada variabel yang harus dikeluarkan dari model. Variabel yang harus dikeluarkan dari model apabila variabel memiliki nilai Std. Deviation 0 (nol). Hal ini dikarenakan semua variabel tersebut dibutuhkan dalam melihat preferensi konsumen dalam pembelian Edamame dalam kemasan (beku) (beku) di Jember. Pada 10 variabel di atas layak untuk di analisis secara statistik dan dapat dilakukan analisis faktor untuk menguji kelayakan variabel dengan melihat nilai $K M O$ and Bartlett's Test serta nilai MSA.

\section{Pengujian KMO and Bartlett's Test}

Angka MSA pada Uji KMO and Bartlett's Test dapat diketahui pada output bagian Antiimage correlation, pada angka korelasi yang bertanda $\alpha$ (arah diagonal dari kiri atas ke kanan bawah). Uji KMO and Bartlett's Test digunakan untuk menguji dan mengukur hubungan antar semua variabel yang di gunakan. Hasil Uji $K M O$ and Bartlett's Test adalah sebagai berikut (Tabel

Tabel 2. Hasil Uji KMO and Bartlett's Test Pertama

\begin{tabular}{lrr}
\hline Kaiser-Meyer-Olkin Measure of Sampling Adequacy. & 0.619 \\
Bartlett's Test of Sphericity & Approx. Chi-Square & 131.331 \\
& df & 45 \\
& Sig. & 0.000 \\
\hline
\end{tabular}

Sumber: Data Primer Diolah

Hasil dari Uji KMO and Bartlett's Test yang pertama menunjukkan nilai MSA (Measurement of Sampling Adequency) sebesar 0,619 artinya angka KMO and Bartlett's Test adalah 0.619 dengan signifikansi 0.000. karena angka tersebut sudah diatas 0.5 dengan signifikansi jauh dibawah 0.05
(< 0.05), maka variabel tersebut sudah dapat dianalisis lebih lanjut. Hasil Anti-image correlation yang bertanda $\alpha$ menandakan besarnya MSA sebuah variabel yang nilai MSA nya diatas 0,5 maka variabel tersebut dapat di analisis lebih 
Tabel 3. Hasil Anti Image Matrices Pada Uji KMO pertama

\begin{tabular}{lc}
\hline Variabel & Nilai MSA \\
\hline Harga & 0.551 \\
Kebersihan & 0.710 \\
Daya tahan produk & 0.612 \\
Distribusi/pengecer & 0.632 \\
Rasa & 0.679 \\
Warna & 0.622 \\
Aroma & 0.609 \\
Merek & 0.530 \\
kapasitas isi & 0.605 \\
cepat saji & 0.556 \\
\hline
\end{tabular}

Sumber: Data Primer Diolah

Pada nilai Anti-image correlation tidak ada variabel yang memiliki nilai kurang dari 0.5 . Apabila tidak ada variabel lagi yang memiliki nilai MSA dibawah 0.5 maka kesepuluh variabel tersebut sudah dapat dilakukan analisis faktor. Pada analisis faktor, terdapat 10 variabel yang dapat dilakukan analisis faktor. Terdapat 4 Rotated Componen Matrix yang sesuai dengan jumlah faktor yang didapat. Berikut ini Tabel 4 hasil Rotated Componen Matrix setelah dilakukan analisis faktor.

Tabel 4. Hasil Rotated Componen Matrix

\begin{tabular}{lcccc}
\hline \multirow{2}{*}{ Variabel } & \multicolumn{4}{c}{ Komponen } \\
\cline { 2 - 5 } & 1 & 2 & 3 & 4 \\
\hline Harga & -.125 & $\mathbf{. 8 8 2}$ & .095 & -.006 \\
Kebersihan & .407 & .409 & $\mathbf{. 5 6 7}$ & .036 \\
Daya tahan produk & .043 & .054 & $\mathbf{. 7 9 1}$ & .101 \\
Distribusi/pengecer & .334 & .752 & -.160 & .003 \\
Rasa & $\mathbf{. 5 2 4}$ & .169 & .290 & -.361 \\
Warna & $\mathbf{. 9 0 4}$ & -.025 & .059 & -.014 \\
Aroma & $\mathbf{. 8 7 2}$ & .086 & .096 & .191 \\
Merek & .060 & -.070 & .123 & $\mathbf{. 8 7 4}$ \\
kapasitas isi & .024 & .497 & .344 & $\mathbf{. 6 3 8}$ \\
cepat saji & .091 & -.111 & $\mathbf{. 7 1 3}$ & .113 \\
\hline
\end{tabular}

Sumber: Data Primer Diolah Tahun 2011

Pengelompokan variabel yang membentuk faktorfaktor dari hasil variabel Rotated Componen Matrix yang kemudian didapatkan 10 variabel mengelompokan menjadi 4 faktor, antara lain (Tabel 5)

Faktor 1 : Rasa, Aroma, Warna ( kualitas edamame)

Table 5. Pengaruh Faktor Terhadap Varians

\begin{tabular}{cccc} 
keterangan & Eigenvalue & \%varians & $\%$ cumulative \\
\hline 1 & 2.160 & 21.595 & 21.595 \\
2 & 1.815 & 18.155 & 39.750 \\
3 & 1.721 & 17.214 & 56.964 \\
4 & 1.362 & 13.618 & 70.582 \\
\hline
\end{tabular}


Sumber: Data Primer Diolah

Berdasarkan Tabel 5, pengaruh faktor-faktor tersebut ditunjukkan melalui nilai total cumulative sebesar $70,58 \%$ yang artinya bahwa faktor-faktor yang mempengaruhi terhadap preferensi konsumsi
Edamame dalam kemasan (beku) di Jember sebesar $70,58 \%$. Sisanya di pengaruhi oleh faktor lain yang belum dimasukkan dalam model sebesar 29,42

Tabel 6. Hasil Analisis Variabel Yang membentuk Preferensi Konsumen Dalam Pembelian Edamame Dalam Kemasan (beku) Di Jember.

\begin{tabular}{lc}
\hline \multicolumn{1}{c}{ Faktor } & Persentase Varians \\
\hline Faktor 1 (kualitas produk) & 21.595 \\
Faktor 2 (bauran pemasaran) & 18.155 \\
Faktor 3 (kehandalan) & 17.214 \\
Faktor 4 (desain kemasan) & 13.618 \\
\hline Sumber: Data Primer Diolah &
\end{tabular}

$$
\text { Sumber: Data Primer Diolah }
$$

Persentase varians menunjukkan besarnya pengaruh masing-masing faktor yang mempengaruhi preferensi konsumen dalam pembelian Edamame dalam kemasan (beku) di Jember.

\section{b. Faktor Faktor Yang Membentuk Preferensi Konsumen Dalam Pembelian Edamame curah (segar)}

Terdapat 10 variabel yang dianalisis berpengaruh terhadap preferensi konsumen dalam pembelian Edamame dalam kemasan (beku) dan Edamame curah (segar) yaitu harga, kebersihan, daya tahan produk, distribusi/pengecer, rasa, warna, aroma, ukuran, jumlah polong, kecacatan. Pada Tabel 7 dapat dilihat hasil pengujian standart deviasi dari sepuluh faktor.

Tabel 7. Hasil Pengujian Standar Deviasi

\begin{tabular}{lllccc}
\multicolumn{1}{c}{ variabel } & N & Minimum & Maximum & Mean & Std. Deviation \\
\hline Harga & 50 & 1 & 5 & 3,98 & 0,98 \\
Kebersihan & 50 & 3 & 5 & 4,28 & 0.73 \\
Daya tahan produk & 50 & 3 & 5 & 4,24 & 0.66 \\
Distribusi /pengecer & 50 & 2 & 5 & 3,58 & 0.83 \\
Rasa & 50 & 3 & 5 & 4,1 & 0.68 \\
Warna & 50 & 3 & 5 & 4,08 & 0.69 \\
Aroma & 50 & 2 & 5 & 4 & 0.83 \\
Ukuran & 50 & 2 & 5 & 3,52 & 0.9 \\
Jumlah polong & 50 & 2 & 5 & 3,36 & 1.02 \\
Kecacatan & 50 & 3 & 5 & 4,18 & 0.69 \\
Valid N (listwise) & 50 & & & &
\end{tabular}

Sumber: Data primer diolah

Pada Tabel 7 dapat dilihat bahwa tidak ada variabel yang harus dikeluarkan dari model. Variabel yang harus dikeluarkan dari model apabila variabel memiliki nilai Std. dengan melihat nilai KMO and Bartlett's Test serta nilai MSA.

\section{Pengujian KMO and Bartlett's Test}

Angka MSA pada Uji KMO and Bartlett's Test dapat diketahui pada output bagian Antiimage correlation, pada angka korelasi yang bertanda $\alpha$ (arah diagonal dari kiri atas ke kanan bawah). Uji KMO and Bartlett's Test digunakan untuk menguji dan mengukur hubungan antar semua variabel yang di gunakan (Tabel 8) 
Tabel 8. Hasil Uji KMO and Bartlett's Test Pertama

\begin{tabular}{|c|c|c|}
\hline Kaiser-Meyer-Olkin Measu & ng Adequacy. & 0.664 \\
\hline Bartlett's Test of Sphericity & Approx. Chi-Square & 292.5 \\
\hline & df & \\
\hline & Sig. & .06 \\
\hline
\end{tabular}

Sumber: Data Primer Diolah

Hasil dari Uji KMO and Bartlett's Test yang pertama menunjukkan nilai MSA (Measurement of Sampling Adequency) sebesar 0,664 artinya angka KMO and Bartlett's Test adalah 0.664 dengan signifikansi 0.000 . karena angka tersebut sudah diatas 0.5 dengan signifikansi jauh dibawah 0.05
$(<0.05)$, maka variabel tersebut sudah dapat dianalisis lebih lanjut. Setiapvariabel

dilakukan analisis dengan tujuan untuk mengetahui variabel mana yang dapat dianalisis lebih lanjut dan variabel mana yang harus di keluarkan.

Tabel 9. Hasil Anti Image Matrices Pada Uji KMO pertama

\begin{tabular}{lc}
\hline \multicolumn{1}{c}{ Variabel } & Nilai MSA \\
\hline Harga & 0.354 \\
Kebersihan & 0.470 \\
Daya tahan produk & 0.588 \\
Distribusi /pengecer & 0.774 \\
Rasa & 0.632 \\
Warna & 0.633 \\
Aroma & 0.774 \\
Ukuran & 0.697 \\
Jumlah polong & 0.673 \\
Kecacatan & 0.728
\end{tabular}

Sumber: Data Primer Diolah

Pada nilai Anti-image correlation terdapat beberapa variabel yang memiliki nilai kurang dari 0.5 yaitu harga dan kebersihan. Kedua variabel tersebut dikeluarkan satu persatu dimulai dari nilai
MSA (Measurement of Sampling Adequency) yang terkecil terlebih dahulu yaitu harga dengan MSA 0,354 dan dilanjutkan variabel yang lebih besar yaitu kebersihan dengan MSA 0.470 .

Tabel 10. Hasil dari Uji KMO and Bartlett's Test kedua

\begin{tabular}{llr}
\hline Kaiser-Meyer-Olkin Measure of Sampling Adequacy. & .686 \\
Bartlett's Test of Sphericity & Approx. Chi-Square & 282.230 \\
& df & 36 \\
& Sig. & .000
\end{tabular}

Sumber: Data Primer Diolah

Pada hasil uji KMO yang kedua telah dikeluarkan variabel harga. Hasil uji KMO yang kedua menunjukkan nilai MSA (Measurement of Sampling Adequency) 0.686 artinya angka $K M O$ and Bartlett's 0.686 dengan signifikansi Dengan dikeluarkannya variabel kemasan terlihat kenaikan angka MSA dari 0.664 ke 0.686. Pada hasil AntiImage correlation untuk uji KMO kedua sudah berkurang dan mengeluarkan angka MSA lagi yang paling kecil atau kurang dari 0.5 . 
Tabel 11 Hasil Anti Image Matrices Pada Uji KMO Kedua

\begin{tabular}{lc}
\hline \multicolumn{1}{c}{ Variabel } & Nilai MSA \\
\hline Kebersihan & 0.478 \\
Daya tahan produk & 0.578 \\
Distribusi /pengecer & 0.813 \\
Rasa & 0.675 \\
Warna & 0.638 \\
Aroma & 0.797 \\
Ukuran & 0.714 \\
Jumlah polong & 0.669 \\
Kecacatan & 0.746 \\
\hline
\end{tabular}

Sumber: Data Primer Diolah

Pada Tabel 11 dapat dilihat bahwa ada variabel yang harus dikeluarkan dari model yaitu variabel kebersihan. Variabel kebersihan dikeluarkan dari model karena nilai MSA kurang dari 0.5.

Tabel 12. Hasil Dari Uji KMO And Bartlett's Test Ketiga

Kaiser-Meyer-Olkin Measure of Sampling Adequacy.

Bartlett's Test of Sphericity

Approx. Chi-Square

229.944

df

Sig.

0.000

Pada hasil uji KMO yang ketiga telah dikeluarkan variabel merel $\left(\mathrm{X}_{2}\right)$. Hasil uji $\mathrm{KMO}$ yang ketiga menunjukkan nilai MSA 0.730 artinya angka KMO and Bartlett's 0.730 dengan signifikansi 0.000 . karena angka tersebut diatas 0.5 dengan signifikansi jauh dibawah $0.05(<$
0.05), maka variabel tersebut sudah dapat dianalisis lebih lanjut. Dengan dikeluarkannya variabel kebersihan terlihat kenaikan angka MSA dari 0.686 ke 0.730 . apabila tidak ada variabel lagi yang memiliki nilai MSA dibawah 0.5 maka kedelapan variabel tersebut sudah dapat dilakukan analisis faktor (Tabel 12)

Tabel 13. Hasil Anti Image Matrices Pada Uji KMO Ketiga

\begin{tabular}{lc}
\hline \multicolumn{1}{c}{ Variabel } & Nilai MSA \\
\hline Daya tahan produk & 0.692 \\
Distribusi /pengecer & 0.808 \\
Rasa & 0.647 \\
Warna & 0.824 \\
Aroma & 0.814 \\
Ukuran & 0.674 \\
Jumlah polong & 0.643 \\
Kecacatan & 0.733 \\
\hline
\end{tabular}

Sumber: Data Primer Diolah Tahun 2011

Pada analisis faktor, terdapat 8 variabel yang dapat dilakukan analisis faktor. Terdapat 2 Componen Matrix Ratated yang sesuai dengan jumlah faktor yang didapat. Berikut ini Tabel 14 hasil Componen Matrix Ratated setelah dilakukan analisis faktor. 
Tabel 14. Hasil Component Matrix Ratated

\begin{tabular}{lcccc} 
& Variabel & 1 & & 2 \\
\hline Daya tahan produk & & 0.099 & $\mathbf{0 . 7 4 6}$ \\
Distribusi /pengecer & & 0.079 & & 0.432 \\
Rasa & 0.270 & & $\mathbf{0 . 8 3 5}$ \\
Warna & 0.539 & & $\mathbf{0 . 7 3 6}$ \\
Aroma & & $\mathbf{0 . 8 8 7}$ & & 0.099 \\
Ukuran & & $\mathbf{0 . 9 3 7}$ & & 0.067 \\
Jumlah polong & $\mathbf{0 . 6 0 6}$ & 0.397 \\
Kecacatan
\end{tabular}

Sumber: Data Primer Diolah

Pengelompokan variabel yang membentuk faktor-

kemudian didapatkan 8 variabel mengelompokan faktor dari hasil variabel Componen Matrix yang menjadi 2 faktor, antara lain (Tabel 15).

Table 15. Pengaruh Faktor Terhadap Varians

\begin{tabular}{cccc}
\hline \multirow{2}{*}{ keterangan } & Eigenvalue & \%varians & \% cumulative \\
\hline 1 & 2.871 & 35.893 & 35.893 \\
2 & 2.677 & 33.468 & 69.361 \\
\hline
\end{tabular}

Sumber: Data Primer Diolah

Berdasarkan Tabel 15, pengaruh faktor-faktor tersebut ditunjukkan melalui nilai total cumulative sebesar $69,361 \%$ yang artinya bahwa faktor-faktor yang mempengaruhi terhadap preferensi konsumen dalam pembelian Edamame curah (segar) di Jember sebesar $61,37 \%$. Sisanya di pengaruhi oleh faktor lain yang belum dimasukkan dalam model sebesar $38,63 \%$

Table 16. Hasil Analisis Variabel Yang Membentuk Preferensi Konsumen Dalam Pembelian Edamame curah (segar) Di Jember.

\begin{tabular}{lc}
\hline Faktor & Persentase Varians \\
\hline Faktor 1(Eksternal) & 35,893 \\
Faktor 2 (Internal) & 33,468 \\
\hline
\end{tabular}

Sumber: Data Primer Diolah

Persentase varians menunjukkan besarnya pengaruh masing-masing faktor yang mempengaruhi Preferensi konsumen dalam pembelian Edamame curah (segar) di Jember. Berdasarkan tabel 16 menunjukkan bahwa bahwa faktor eksternal memiliki pengaruh terbesar yaitu $35,893 \%$ sedangkan faktor internal memiliki pengaruh sebesar 33,468 .

c. Faktor-Faktor Bauran Pemasaran Yang Mempengaruhi Preferensi Konsumen Dalam Pembelian Edamame Dalam Kemasan (beku) di Jember.

Analisis regresi linier berganda di gunakan untuk mengetahui pengaruh faktor-faktor bauran pemasaran yang terdiri dari produk, harga, tempat, promosi yang mempengaruhi preferensi konsumen dalam pembelian Edamame dalam kemasan (beku) di Jember. Hasil yang digunakan adalah nilai Fhitung, nilai signifikasi t-hitung, dan nilai koefisien determinasi (adjusted $R^{2}$ ). Setelah dilakukan pengujian asumsi klasik, maka dilakukan uji $\mathrm{F}$ terhadap model regresi yang dianggap baik. Model regresi yang diujikan adalah persamaan regresi yang terdiri atas 1 variabel terikat yaitu variabel pembelian konsumen/konsumsi dan sebagai variabel bebas yaitu harga edamame (HE) produk (Prod) promosi (Prom) dan distribusi (Dist), hasil perhitungan tersebut (uji $\mathrm{F}$ dan uji $\mathrm{T}$ ) dapat dilihat pada Tabel 17 berikut. 
Table 17 Hasil Analisis Regresi Linear Berganda Dari Faktor - Faktor Yang Mempengaruhi Pembelian Edamame dalam kemasan (beku) Di Jember.

\begin{tabular}{ccccc}
\hline Variabel bebas & $\begin{array}{c}\text { Koefisien } \\
\text { regresi }\end{array}$ & Standar Error & T-hitung & Sig (0.05) \\
\hline Harga & -.059 & .100 & -.593 & .556 \\
Produk & .372 & .144 & 2.580 & .013 \\
Promosi & .421 & .117 & 3.597 & .001 \\
Tempat & .085 & .128 & .666 & .509 \\
Konstanta & 2.175 & & & \\
\hline $\mathrm{R}^{2}$ & 0.471 & & & 0.000 \\
\hline
\end{tabular}

Sumber: Data Primer Diolah

*) berpengaruh nyata pada taraf kepercayaan $95 \%$

Pada Tabel 17 menunjukkan bahwa nilai Fhitung sebesar 10.018 dengan tingkat signifikan 0,000. Diketahui tingkat signifikan jauh lebih kecil dengan 0,05 maka dapat di simpulkan bahwa model regresi yang diduga dapat di gunakan untuk memprediksi pembelian/konsumsi Edamame dalam kemasan (beku). Sehingga hipotesis $\left(\mathrm{H}_{0}\right)$ dalam penelitian ini yaitu ada pengaruh yang signifikan antara variabel harga, produk, promosi dan distribusi terhadap pembelian Edamame dalam kemasan (beku) di Jember. Hasil uji regresi linear berganda menghasilkan persamaan regresi linear berganda sebagai berikut:
Besarnya pengaruh variabel-variabel yang mempengaruhi konsumsi Edamame dalam kemasan (beku) di Jember dapat diketahui dari nilai $R^{2}$ yaitu 0,471 yang berarti bahwa $47,1 \%$ variasi fungsi konsumsi Edamame dalam kemasan (beku) dipengaruhi oleh variabel bebas yang dimasukkan dalam model, sedangkan sisanya $52,9 \%$ dipengaruhi oleh variabel-variabel lain diluar model.

Y= 2.175 - 0.059 HE + 0.372 Prod + 0.421 Prom + 0.085

Dist

Table 18 Hasil Analisis Regresi Linear Berganda Pada Faktor- Faktor Yang Mempengaruhi Pembelian Edamame curah (segar) Di Jember.

\begin{tabular}{ccccc}
\hline Variabel bebas & Koefisien regresi & Standar Error & t-hitung & Sig (0.05) \\
\hline Harga & -0.108 & 0.096 & -1.133 & 0.263 \\
Produk & 0.178 & 0.150 & 1.191 & 0.240 \\
Promosi & 0.459 & 0.098 & 4.697 & 0.000 \\
Tempat & 0.057 & 0.126 & 0.456 & 0.651 \\
Konstanta & 7.399 & & & \\
$R^{2}$ & 0.495 & & & 0,000 \\
F-hitung & 11.043 & & & \\
\hline
\end{tabular}

Sumber: Data Primer Diolah

Pada Tabel 18 menunjukkan bahwa nilai Fhitung sebesar 11.043 dengan tingkat signifikan 0,000 . Diketahui tingkat signifikan $(0,000)$ jauh lebih kecil dengan 0,05 maka dapat di simpulkan bahwa model regresi yang diduga dapat di gunakan untuk memprediksi pembelian Edamame curah (segar), Sehingga hipotesis $\left(\mathrm{H}_{0}\right)$ dalam penelitian ini yaitu ada pengaruh yang signifikan antara variabel harga, produk, promosi dan distribusi terhadap keputusan konsumsi Edamame curah (segar) di Jember.Pada Tabel 18 diketahui hasil analisis regresi linear berganda menghasilkan persamaan regresi linear berganda sebagai berikut: 
$\mathrm{Y}=7.399-0.108 \mathrm{HE}+0.178$ Prod + 0.459 Prom + 0.057 Dist

Hasil koefisiensi regresi dari masing masing variabel yang mempengaruhi pembelian curah segar di Jember adalah sebagai berikut:

\section{Harga (HE)}

Harga merupakan sejumlah uang yang di bayarkan terhadap produk tersebut. Nilai koefisen regresi harga Edamame curah (segar) sebesar -0.108. Koefisien regresi variabel harga menunjukkan angka negatif, jika harga mengalami peningkatan sebesar 1 (satu) poin sementara produk dan promosi dianggap tetap, maka akan menyebabkan penurunan preferensi konsumsi edamame sebesar 0.108 point

\section{Produk (Prod)}

Produk merupakan segala sesuatu yang ditawarkan kepada suatu pasar untuk memenuhi keinginan atau kebutuhan, pada penelitian ini produk yang dimaksud adalah Edamame curah (segar). Nilai koefisien regresi produk adalah sebesar 0,178 yang memiliki pengaruh positif yaitu jika produk mengalami peningkatan sebesar 1 (satu) point sementara harga, promosi dan distribusi dianggap tetap, maka akan menyebabkan kenaikan keputusan pembelian sebesar 0,178 point.

3. Promosi (Prom)
Promosi merupakan penyampaian informasi tentang edamame, manfaat serta membujuk konsumen untuk konsumsi produk edamame. Produk yang di maksud adalah produk Edamame curah (segar).

\section{Distribusi (Dist)}

Distribusi merupakan penetapan tempat seorang produsen atupun distributor dalam menyampaikan produk Edamame curah (segar) kepada konsumen baik secara langsunga atau dengan perantara. Nilai koefisien regresi distribusi Edamame curah (segar) sebesar 0,057. Koefisien regresi variabel distribusi menunjukkan

Strategi Pengembangan Edamame di Kabupaten Jember

Strategi pengembangan edamame di Kabupaten Jember dapat menggunakan analisis medan kekuatan (FFA / Force Field Analysis). FFA merupakan prosedur analisis yang sederhana, relevan dan diperlukan agar dapat diperoleh suatu solusi, sedangkan solusi tersebut dapat berasal dari isu-isu strategis sebagai identifikasi pengembangan edamame di Jember. Kemudian dari solusi beserta aktivitasnya dapat dijadikan bahan pertimbangan yang cukup relevan dan dapat diajdikan prioritas bagi pengembangan edamame di Kabupaten Jember.

Tabel 19. Faktor Pendorong dan Penghambat Pengembangan Pasar Lokal Edamame di Kabupaten Jember

\begin{tabular}{|c|c|c|c|}
\hline \multicolumn{3}{|c|}{ Faktor Pendorong } & \multirow{2}{*}{$\frac{\text { Faktor Penghambat }}{\text { Weaknesses }}$} \\
\hline & Strenght & & \\
\hline S 1 & Komoditi relatif baru & $\mathrm{W} 1$ & Jumlah outlet terbatas \\
\hline S 2 & Bahan baku tersedia (Edamame) & W2 & Jarak konsumen dengan outlet \\
\hline S 3 & Kualitas ekspor & W3 & Produk Mudah Rusak \\
\hline & Opportunities & & Threats \\
\hline $\mathrm{O} 1$ & Rasa khas dan ukuran biji besar & $\mathrm{T} 1$ & Belum ada tempat penyimpanan \\
\hline $\mathrm{O} 2$ & $\begin{array}{l}\text { Adanya image positif konsumen thd } \\
\text { edamame }\end{array}$ & Т 2 & $\begin{array}{l}\text { Kurangnya informasi produk edamame pada } \\
\text { konsumen }\end{array}$ \\
\hline
\end{tabular}

Berdasarkan hasil analisis FFA mengenai penilaian faktor pendorong dan faktor penghambat yang disajikan pada Tabel 20 Evaluasi Faktor
Pendorong dan Faktor Penghambat maka dapat diketahui nilai Total Nilai Bobot (TNB) masingmasing faktor. 
Tabel 20. Evaluasi Faktor Pendorong dan Faktor Penghambat Pengembangan Pasar lokal edamame di Kabupaten Jember

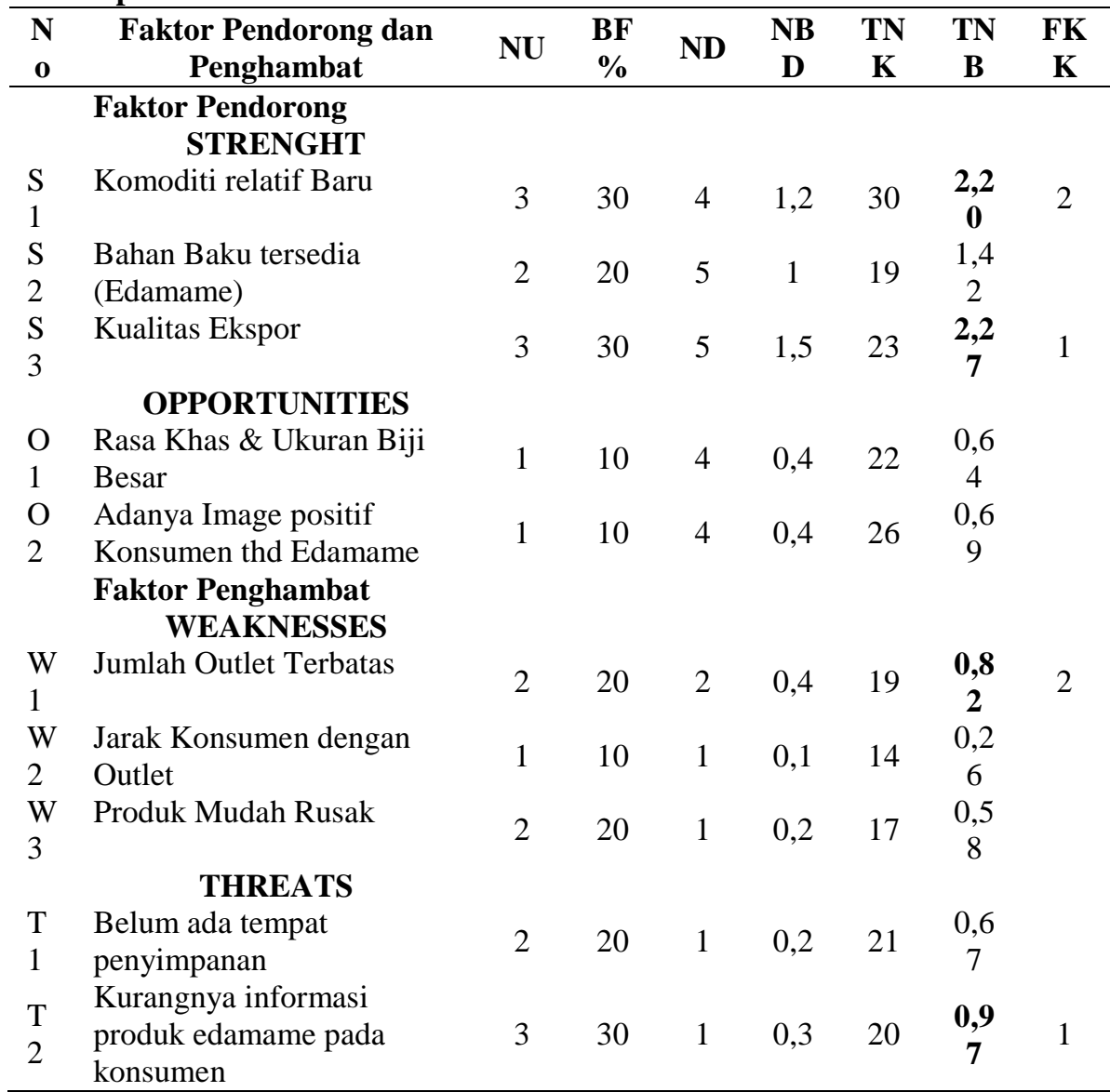

Sumber: Data Primer Olahan Tahun 2011

Keterangan: *) = merupakan prioritas Faktor Kunci Keberhasilan

\section{KESIMPULAN DAN SARAN}

\section{KESIMPULAN :}

Berdasarkan hasil penelitian dan pembahasan, maka dapat diambil kesimpulan sebagai berikut:

1. Preferensi konsumen dalam pembelian edamame kemasan (beku) di pengaruhi oleh variable produk dan promosi, sedangkan harga edamame dan distribusi tidak memiliki pengaruh nyata.

2. Faktor-faktor yang membentuk preferensi konsumen dalam pembelian edamame dalam kemasan (beku) di Jember yaitu faktor kualitas edamame meliputi variabel rasa, aroma, warna. Faktor bauran pemasaran meliputi harga, distribusi/pengecer. Faktor kehandalan meliputi kebersihan, daya tahan produk, cepat saji. Faktor desain kemasan meliputi kapasitas isi dan merek.

3.Hasil analisis force field analysis menyatakan bahwa faktor pendorong utama dalam pengembangan edamame di Kabupaten Jember adalah kualitas ekspor edamame dan kedua adalah produk edamame yang relatif baru bagi masyarakat.

\section{SARAN}

1. Konsumen edamame dalam kemasan selain memperhatikan produk juga memperhatikan promosi, sehingga sebaiknya produsen membuat inovasi produk edamame dalam kemasan dan pengembangan promosi.

2. Dalam memproduksi edamame tetap mengutamakan produk dengan standart ekspor yang dipasarkan di Kabupaten Jember. Kemudian memanfaatkan bauran dari produk edamame ini dengan menjual edamame di berbagai wilayah di Kabupaten Jember

\section{DAFTAR PUSTAKA}

Dewi D. P. 2010. Analisis Tipe Preferensi Konsumen Dalam Membeli Teh di Pasar 
Tradisional Kabupaten Wonogiri. Surakarta; Fakultas pertanian Universitas sebelas maret Edwarsyah. 2004. Analisis Sikap dan Preferensi Konsumen terhadap Produk Mie Instan. Jakarta; Thesis S2, MM Universitas Budi Luhur

Engel, James. F; Roger D. Blackwell and Paul W. Miniard. 1994. Preferensi Konsumen. Edisi keenam Jilid 1. Binarupa Aksara. Jakarta.

Haliana, Novel. 2008. Analisis faktor-faktor yang mempengaruhi Konsumen dalam pengambilan keputusan Pembelian produk mie instan merek indomie. Jakarta : Universitas Gunadarma.

Koutsoyiannis, A. 1976. Theory of Econometrics; An Introductory Exposition of Econometrics Method, Second Edition. London: The Macmilan Publisher.

Kotler, Philip. 2000. Manajemen Pemasaran (terjemahan). Edisi Millenium. Jilid 1. PT. Prenhallindo. Jakarta.

Kusnendi. (2008). Model Model Persamaan Struktural. Bandung : Alfabeta

Lamb, Hair, Mc Daniel. 2001. Pemasaran (terjemahan). Edisi Bahasa Indonesia, Jilid Pertama. Salemba Empat.Jakarta

Riza Wahyu Utami, 2008. Analisis Preferensi Terhadap Prospek Pemasaran Kopi Bubuk "555". Tesis Magister Agribisnis, Program Pasca Sarjana Universitas Jember.

Salvatore, D. 1997. Teori Ekonomi Mikro. Terjemahan Edisi Ketiga. Penerbit Erlangga. Jakarta.

Simamora, B. 2004. Panduan Riset Preferensi Konsumen. Gramedia Pustaka. Jakarta

Sigit Samsu (2001). Sebuah Pengalaman Diri. Membangun Agroindustri Bernuansa Ekspor Edamame (Vegetable Soybean) bersama Mitratani Dua Tujuh Jember

Stanton, William J. 1993. Prinsip Pemasaran (terjemahan). Edisi 7. Jilid 1.Erlangga. Jakarta.
Surakhmad. 1994. Pengantar Penelitian Ilmiah. Tarsito. Bandung.

Suharyadi, 2004. Statistika. Edisi 2. Salemba Empat. Jakarta

Swastha, B dan T. Hani H. 1987. Manajemen Pemasaran; Analisa Preferensi Konsumen. Yogyakarta: Liberty

Swastha, Basu DH dan T. Hani Handoko. 1996. Manajemen Pemasaran, Analisa Preferensi Konsumen , Edisi kedua, Yogyakarta: Liberty,

Tedjakusuma, R, Hartini, S dan Muryani. 2001. Analisis factor-faktor yang mempengaruhi preferensi konsumen dalam pembelian air minum mineral di Kotamadya Surabaya. Surabaya. Jurnal Penelitian Dinamika Sosial: Universitas Airlangga Surabaya.

Tomek, W,G and Kenneth Robinson. 1990. Agricultural Product Prices, Third Edition. Cornell University Press.

Umar husen. 2003. Metode Riset preferensi konsumen jasa. Ghalia Indonesia. Jakarta

Widodo, S. 2008. Ekonomi Mikro, Hand out Program Pasca Sarjana Ekonomi Pertanian Universitas Gadjahmada. Yogyakarta

Widarjono, A. 2007. Ekonometrika: Teori dan Aplikasi untuk Ekonomi dan Bisnis; Edisi Kedua. Yogyakarta: Ekonesia FE UII.

Widodo, E dan Mukhtar. 2000. Konstruksi ke arah Penelitian Deskriptif. Avyorus. Yogyakarta

Wiyono, L.C. 2010. Prospek Agribisnis Edamame di Kabupaten Jember. Tesis S2 Fakultas Pertanian Universitas Gadjah Mada. Yogyakarta.

, L.C. 2011. Analisis Permintaan Edamame di Kabupaten Jember. Jember. Jurnal Inovasi: Politeknik Negeri Jember.

Wirijadinata.2010. Implementasi Force Field Analysis(analisis Medan Kekuatan)From: http://usepmulyana.files.wordpress.com/2009/02/i mplementasi-forced-field-analysis-change.pdf, 20 Maret 2011 